\title{
PENGGUNAAN MODEL PEMBERIAN PERINTAH (MODEL KOMANDO) DALAM UPAYA MENINGKATKAN PRESTASI BELAJAR PENJASORKES SISWA KELAS XII IPA 1 SMA NEGERI 1 KUTA
}

\section{THE USE OF THE COMMAND MODEL IN THE EFFORT TO INCREASE THE STUDENTS' LEARNING ACHIEVEMENT IN CLASS XII IPA 1 SMA NEGERI 1 KUTA}

\author{
I Made Sudarma* \\ SMA Negeri 1 Kuta, Badung, Bali, Indonesia \\ *Email Penulis korespondensi: sudarmaimade@gmail.co.id
}

\begin{abstract}
Abstrak
Penelitian tindakan kelas yang dilaksanakan ini memiliki tujuan untuk meningkatkan prestasi belajar Penjasorkes. Perolehan data awal yang rendah pada siswa kelas XII.IPA 1 SMA Negeri 1 Kuta semester I tahun pelajaran 2020/2021 membuat peneliti mengupayakan membenahi proses yang kurang baik yang telah dilaksanakan. Perbaikan proses pembelajaran dilakukan melalui penggunaan model pemberian perintah (model komando). Model ini diharapkan dapat memecahkan permasalahan yang sedang dihadapi. Setelah data dikumpulkan melalui instrumen tes prestasi belajar, diperoleh peningkatan hasil belajar dengan data awal yang rata-rata kelasnya yaitu mencapai 79,58 dengan prosentase ketuntasan belajar baru mencapai 33,33\%, pada siklus I meningkat menjadi 84,97 rata-rata kelas dan 77,78\% untuk ketuntasan belajarnya. Sedangkan pada siklus II data tersebut telah meningkat menjadi 90,72 rata-rata kelasnya dan $100 \%$ ketuntasan belajarnya. Data pada Siklus II ini sudah menunjukkan keberhasilan pelaksanaan pembelajaran yang melebihi indikator yang dipersyaratkan. Oleh karenanya peneliti mengambil simpulan bahwa penggunaan model pemberian perintah (model komando) dalam melaksanakan proses pembelajaran mampu meningkatkan prestasi belajar Penjasorkes.
\end{abstract}

Kata-Kata Kunci: Model Pemberian Perintah (Model Komando); Prestasi Belajar Penjasorkes

\begin{abstract}
This classroom action research was carried out with the aim of improving physical education and sports learning achievement. The low initial data acquisition for students of class XII.IPA 1 SMA Negeri 1 Kuta in the first semester of the 2020/2021 academic year made researchers seek to fix the poor processes that had been implemented. Improvement of the learning process is carried out through the use of the command model (command model). This model is expected to solve the problems being faced. After the data was collected through the learning achievement test instrument, an increase in learning outcomes was obtained with the initial data that the class average reached 79.58 with the percentage of new learning completeness reaching $33.33 \%$, in the first cycle it increased to 84.97 the class average and $77.78 \%$ for complete learning. While in the second cycle the data has increased to 90.72 the class average and $100 \%$ complete learning. The data in Cycle II has shown the success of the learning implementation that exceeds the required indicators. Therefore, the researcher concludes that the use of the command model (command model) in carrying out the learning process is able to improve physical education learning achievement.
\end{abstract}

Keywords: Command Giving Model (Command Model); Physical Education Learning Achievement

\section{PENDAHULUAN}

Mata pelajaran pendidikan jasmani olahraga dan kesehatan bertujuan untuk mengembangkan dasar-dasar keterampilan berolahraga. Selain hal tersebut yang diperlukan juga dimaksudkan untuk menguasai berbagai keterampilan yang dapat dimanfaatkan dalam kehidupan mereka kelak di kemudian hari. Menurut para ahli, pola pertumbuhan dan perkembangan anak berbanding terbalik dengan tingkat kecepatannya, pada usia prasekolah 
pertumbuhan yang berhubungan dengan fisik tumbuh begitu cepat. Sedangkan pada usia sekolah hingga menjelang remaja disebut pola pertumbuhan lambat akan tetapi perkembangan yang bersifat psikis atau mental berkembang dengan pesat.

Pendidikan Jasmani Olahraga dan Kesehatan merupakan bagian integral dari pendidikan secara nasional, bertujuan untuk mengembangkan aspek kebugaran jasmani, keterampilan gerak, keterampilan berfikir kritis, keterampilan sosial, penalaran, stabilitas emosional, tindakan moral, aspek pola hidup sehat dan pengenalan lingkungan bersih melalui aktivitas jasmani, olahraga dan kesehatan terpilih yang direncanakan secara sistematis dalam rangka mencapai tujuan pendidikan nasional.

Dalam proses pembelajaran pada mata pelajaran pendidikan jasmani olahraga dan kesehatan guru harus dapat melakukan pendekatan yang menyenangkan sehingga siswa dapat belajar dengan penuh semangat. Keberadaan mata pelajaran pendidikan jasmani olahraga dan kesehatan sebenarnya sangat membantu pengajar pendidikan jasmani dalam mempersiapkan, melaksanakan dan mengevaluasi kegiatan siswa. Adapun ruang lingkup pendidikan jasmani meliputi aspek permainan dan olahraga, aktivitas pengembangan, senam, aktivitas ritmik, akuatik (aktivitas air), pendidikan luar kelas, dan kesehatan. Semua aspek tersebut begitu juga kemampuan yang diperoleh berdampak pada kebugaran jasmani peserta didik.

Hasil observasi awal di SMA Negeri 1 Kuta, pada saat berlangsungnya proses belajar mengajar terlihat bahwa aktivitas terlihat kurang bergairah, peserta didik tidak mempunyai stamina yang baik artinya siswa dalam pembelajaran hanya melakukan sekali dua kali gerakan saja terlihat sudah kelelahan. Kebanyakan mereka hanya sekadar melakukan kewajiban mengikuti pembelajaran saja, tanpa kreativitas dan keinginan yang besar untuk menguasai keterampilan yang diajarkan dengan sebagaik-baiknya. Dari sudut guru sendiri, melihat keberadaan peserta didik tersebut menumbuhkan keinginan yang besar untuk memperbaiki keadaan dalam rangka membantu mereka mencapai ketuntasan belajar seperti yang dipersyaratkan. Setelah dikaji secara seksama, metode mengajar yang diterapkan guru kurang menarik harus segera ditanggulangi dengan memilih metode dan strategi pembelajaran yang lebih kreatif dan inovatif untuk membangkitkan aktivitas dan semangat mereka demi peningkatan prestasi belajar yang diinginkan.

Prestasi belajar Penjasorkes kelas XII.IPA 1 SMA Negeri 1 Kuta semester I tahun pelajaran 2020/2021 yang diperoleh setelah berakhirnya proses pembelajaran untuk yang ketiga kalinya baru mencapai 79,58 dengan ketuntasan belajar 33,33\%. KKM yang ditentukan untuk mata pelajaran Penjasorkes adalah 85,00 dan prosentase ketuntasan belajar yang diperoleh mencapai $85,00 \%$.

Berdasarkan latar belakang dan masalah yang berhasil diidentifikasi menyangkut belum berhasilnya siswa mencapai ketuntasan belajar yang diinginkan dan upaya pemecahan yang akan dilakukan, maka peneliti berhasil merumuskan masalah dalam penelitian ini sebagai berikut : Apakah penggunaan model pemberian perintah (model komando) dapat meningkatkan prestasi belajar Penjasorkes siswa kelas XII.IPA 1 SMA Negeri 1 Kuta semester I tahun pelajaran 2020/2021? Penelitian tindakan kelas ini dilakukan untuk mengatasi berbagai persoalan nyata guna memperbaiki atau meningkatkan kualitas proses pembelajaran di kelas. Apa yang menjadi tujuan dalam penelitian ini disampaikan sebagai berikut: Untuk meningkatkan prestasi belajar Penjasorkes siswa kelas XII.IPA 1 SMA Negeri 1 Kuta semester I tahun pelajaran 2020/2021 dengan penggunaan model pemberian perintah (model komando).

Pembelajaran dengan Model Pemberian Perintah dapat ditandai dengan suatu moment dimana guru yang paling dominan/berperan membuat seluruh keputusan dalam proses belajar mengajar. Dengan kata lain siswa harus mengikuti semua perintah dan petunjuk yang diberikan oleh guru. Setiap gerakan yang dilakukan oleh siswa harus 
mengikuti contoh-contoh yang telah diberikan oleh guru. Dengan demikian, segala keputusan yang berhubungan dengan tempat pelaksanaan, posisi tubuh siswa, penentuan saat untuk memulai kegiatan, irama dan kecepatan serta jangka waktu dari setiap gerakan (intervalnya) harus dilakukan oleh guru (Depdiknas, 2009: 31 - 32). Tahapan yang dilakukan dalam melakukan model pembelajaran Pendidikan Jasmani Olahraga dan Kesehatan sesuai pendapat Depdiknas (2009: 23) ada tiga yakni: a) Tahapan Pre Impact (sebelum inti). Tahap ini adalah proses pendahuluan/pembukaan pelajaran. b) Tahapan Impact (inti). Pada tahapan ini guru terlibat dalam semua kegiatan yang sudah diputuskan pada tahap pre impact. Guru dan siswa mengalami stimulus langsung serta respon pada saat bersamaan. Guru harus yakin bahwa setiap isyarat perintah yang diberikannya telah dipatuhi siswa, dengan melihat bahwa semua siswa melakukan gerakan-gerakan yang sudah ditugaskan dan diberikan contoh sebelumnya. c) Tahapan Post Impact (setelah inti). Dalam tahap ini pada saat proses stimulus respon sedang berlangsung, guru mengamati penampilan setiap siswa serta memberikan umpan balik kepada mereka, kemudian mengamati gerakan-gerakan yang kurang tepat dan memberi petunjuk untuk memperbaikinya secara lisan berupa pernyataan perbaikan, pernyataan penilaian maupun pernyataan netral. Gunakan pernyataan yang cocok dengan situasi yang sedang terjadi. Bila terjadi kesalahan, gunakan umpan balik yang sifatnya memperbaiki (koreksi). Bila penampilan memuaskan, berikan umpan balik penilaian, dan sebagainya.

Dalam pengorganisasian di lapangan, sesuai arahan Depdiknas, bahwa guru mempunyai pilihan dalam melaksanakan model Pemberian Perintah atau model Komando (Depdiknas, 2009: 32) adalah sebagai berikut: a) Pemberian umpan balik terhadap masingmasing siswa secara perorangan. b) Pemberian umpan balik terhadap masing-masing siswa secara perorangan. c) Pemberian umpan balik selama pelaksanaan penampilan. d) Pemberian umpan balik setelah pelaksanaan penampilan.

Dalam melaksanakan model Komandeo, pengaruh umpan balik sangat perlu. Guru harus memuji mana diantara dua jenis umpan balik ini yang cocok untuk disesuaikan dengan situasi dan kondisi siswanya (Depdiknas, 2009: 32 - 33).

Pada saat membuat perencanaan mengenai materi yang akan dilakukan dengan Model Pengajaran pemberian perintah (komando) kita harus memilih gerakan-gerakan atau keterampilan-keterampilan yang cocok dengan karakteristik dari model (Depdiknas, 2009: 33) yaitu: a) Penampilan gerakan secara tepat, segera setelah perintah diberikan. b) Persyaratan yang harus dimiliki bagi terciptanya keterkaitan antara stimulus dengan respon dari gerakan-gerakan atau keterampilan-keterampilan yang dilakukan siswa. Komponen utama untuk memenuhi persyaratan tersebut diantaranya adalah postur tubuh siswa dan irama dari gerakan yang dilakukannya. Bila guru mampu mengamati serta mengawasi postur dan irama selama siswa melakukan gerakan-gerakannya, maka pemilihan bahan pelajaran yang cocok dengan Model ini akan dapat dilakukannya. c) Di dalam pendidikan jasmani, model pengajaran komando dapat kita temukan dalam beberapa kegiatan, yaitu: 1) "Gerakan Tunggal" yang dilakukan oleh sejumlah siswa yang sedang berdiri dengan posisi tubuh tertentu, pada tempat-tempat tertentu dalam mendengarkan serta untuk memberikan respon atau stimulus tertentu yang diberikan oleh gurunya. 2) Pada serangkaian gerakan yang sudah dirancang berdasarkan tahapan-tahapan khusus, misalnya gerakan-gerakan tertentu pada senam lantai, tarian modern, beberapa gerakan pada tarian daerah dan sebagainya. Dalam hal ini, semua gerakan dilakukan berdasarkan serangkaian perintah yang diberikan oleh guru. 3) Beberapa jenis olahraga tertentu, misalnya dayung. Gerakan yang dilakukan oleh semua anggota terjadi secara teratur serta bersama-sama, karena isyarat aba-aba / perintah yang diberikan oleh salah seorang dari regu dayung tersebut yang berperan sebagai pengaturnya. 4) Kegiatan-kegiatan lainnya. 
Djamarah (2013:23) mendefinisikan prestasi belajar sebagai hasil yang diperoleh berupa kesan-kesan yang mengakibatkan perubahan dalam diri individu sebagai hasil dari aktivitas dalam belajar. Kalau perubahan tingkah laku adalah tujuan yang mau dicapai dari aktivitas belajar, maka perubahan tingkah laku itulah salah satu indikator yang dijadikan pedoman untuk mengetahui kemajuan individu dalam segala hal yang diperolehnya di sekolah.

Prestasi belajar merupakan kemampuan-kemampuan yang dimiliki oleh siswa sebagai akibat perbuatan belajar atau setelah menerima pengalaman belajar, yang dapat dikatagorikan menjadi tiga ranah, yakni ranah kognitif, afektif, dan psikomotor yang dalam mencapai tujuan yang telah ditetapkan banyak dipengaruhi oleh berbagai faktor faktor-faktor yang dapat mempengaruhi prestasi belajar menurut Purwanto (2000: 102) antara lain: (1) faktor yang ada pada diri organisme itu sendiri yang dapat disebut faktor individual, seperti kematangan/pertumbuhan, kecerdasan, latihan, motivasi, dan faktor pribadi, (2) faktor yang ada diluar individu yang disebut faktor sosial., seperti faktor keluarga/keadaan rumah tangga, guru dan cara mengajamya, alat-alat yang dipergunakan dalam belajar-mengajar, lingkungan dan kesempatan yang tersedia dan motivasi sosial. Dalam penelitian ini faktor ke 2 yaitu faktor yang dari luar seperti guru dan cara mengajarnya yang akan menentukan prestasi belajar siswa. Guru dalam hal ini adalah kemampuan atau kompetensi guru, pendidikan dan lain-lain. Cara mengajarnya itu merupakan faktor kebiasaan guru itu atau pembawaan guru itu dalam memberikan pelajaran. Juga dikatakan oleh Slamet (2003: 54-70) bahwa faktor-faktor yang mempengaruhi belajar banyak jenisnya, tetapi dapat digolongkan menjadi dua golongan saja, yaitu faktor intern dan faktor ekstem. Faktor intern diklasifikasi menjadi tiga faktor yaitu: faktor jasmaniah, faktor psikologis dan faktor kelelahan. Faktor jasmaniah antara lain: kesehatan, cacat tubuh. Faktor psikologis antara lain: intelegensi, perhatian, minat, bakat, motif, kematangan, kesiapan. Faktor kelelahan antara lain: kelelahan jasmani dan rohani. Sedangkan faktor ekstern digolongkan menjadi tiga faktor yaitu: faktor keluarga, faktor sekolah, faktor masyarakat. Faktor keluarga antara lain: cara orang tua mendidik, relasi antara keluarga, suasana rumah tangga dan keadaan ekonomi keluarga. Faktor sekolah antara lain: metode mengajar, kurikulum, relasi guru dengan siswa, relasi siswa dengan siswa, disiplin sekolah, pelajaran dan waktu sekolah, standar pelajaran, keadaan gedung, metode belajar dan tugas rumah. Faktor masyarakat antara lain: kegiatan siswa dalam masyarakat, mass media, teman bergaul, bentuk kehidupan masyarakat. Peningkatan prestasi belajar yang penulis teliti dalam hal ini dipengaruhi oleh faktor ekstern yaitu metode mengajar guru.

Sardiman (1988: 25) menyatakan prestasi belajar sangat vital dalam dunia pendidikan, mengingat prestasi belajar itu dapat berperan sebagai hasil penilaian dan sebagai alat motivasi.

Prestasi belajar tidak akan bisa diketahui tanpa dilakukan penilaian atas hasil aktivitas belajar siswa. Fungsi prestasi belajar bukan saja untuk mengetahui sejauhmana kemajuan siswa setelah menyelesaikan suatu aktivitas, tetapi yang lebih penting adalah sebagai alat untuk memotivasi setiap siswa agar lebih giat belajar, baik secara individu maupun kelompok. Dalam pembahasan ini akan dibicarakan mengenai prestasi belajar sebagai hasil penilaian dan pada pembahasan berikutnya akan dibicarakan pula prestasi belajar sebagai alat motivasi. Prestasi belajar sebagai hasil penilaian sudah dipahami. Namun demikian untuk mendapatkan pemahaman, perlu juga diketahui, bahwa penilaian adalah sebagai aktivitas dalam menentukan rendahnya prestasi belajar itu sendiri.

Mohammad Surya (1979), mengatakan bahwa faktor-faktor yang mempengaruhi prestasi belajar dapat dilihat dari berbagai sudut pandang, antara lain dari sudut si pebelajar, proses belajar dan dapat pula dari sudut situasi belajar. Dari sudut si pembelajar (siswa), prestasi belajar seseorang dipengaruhi antara lain oleh kondisi kesehatan jasmani siswa, 
kecerdasan, bakat, minat, motivasi, penyesuaian diri dan kemampuan berinteraksi siswa. Sedangkan yang bersumber dari proses belajar, maka kemampuan guru dalam mengelola proses pembelajaran sangat menentukan prestasi belajar siswa. Guru yang menguasai materi pelajaran dengan baik, menggunakan metode dan media pembelajaran yang tepat, mampu mengelola kelas dengan baik dan memiliki kemampuan untuk menumbuhkembangkan motivasi belajar siswa untuk belajar, akan memberi pengaruh yang positif terhadap prestasi belajar siswa.

Konsep pendidikan jasmani yang diuraikan Nixon dan Jewet, dapat dikatakan searah dengan pemahaman di Indonesia yang diuraikan Rusli Lutan (2001: 18), bahwa pendidikan jasmani sebagai sebuah subjek yang penting bagi pembinaan fisik yang dipandang sebagai mesin dalam konteks pendidikan jasmani yang mengandung isi pendidikan melalui aktivitas jasmani. Karenanya konsep pendidikan jasmani perlu dikuasai oleh para calon guru (mahasiswa penjas) dan guru yang bersangkutan, sehingga dalam penerapannya memperlihatkan kesetaraan pemahaman.

Selain itu diharapkan dapat melakukan pemetaan konsep dalam penerapan pendidikan jasmani berdasarkan jenjang pendidikan (kesesuaian kurikulum pendidikan jasmani), termasuk memaksimalkan potensi-potensi lokal, dalam hal ini permainan tradisional yang dapat dimodifikasi. Sebagai batasan atau rumusan dari konsep pendidikan jasmani, Arma Abdoellah (2003:42) menguraikan sebagai salah satu aspek dari proses pendidikan keseluruhan peserta didik melalui kegiatan jasmani yang dirancang secara cermat, yang dilakukan secara sadar dan terprogram dalam usaha meningkatkan kemampuan dan keterampilan jasmani dan sosial serta perkembangan kecerdasan.

Esensi dari substansi pendidikan jasmani ialah pengetahuan tentang gerak insani dalam konteks pendidikan yang terkait dengan semua aspek pengetahuan yang berlangsung secara didaktik, rekreatif, untuk dipahami dan dapat dilakukan oleh peserta didik secara utuh. Oleh karena itu, pendidikan jasmani dan olahraga adalah suatu proses pembelajaran melalui aktivitas jasmani yang didesain untuk meningkatkan kebugaran jasmani, mengembangkan keterampilan motorik, pengetahuan dan perilaku hidup sehat dan aktif, sikap sportif, dan kecerdasan emosi. Lingkungan beIajar diatur secara seksama untuk meningkatkan pertumbuhan dan perkembangan seluruh rana, jasmani, psikomotor, kognitif, dan afektif setiap siswa.

Tujuan akhir pendidikan jasmani dan olahraga terletak dalam peranannya sebagai wadah unik. Penyempurnaan watak, dan sebagai wahana untuk memiliki dan membentuk kepribadian yang kuat, watak yang baik dan sifat yang mulia. Jadi orang-orang yang memiliki kebajikan moral seperti inilah yang akan menjadi warga masyarakat yang baik dan berguna. (Baron Piece de Coubertin, Penggagas Kebangkitan Olympiads Modern, Perancis).

Posisi pendidikan jasmani dan olahraga pada kedudukan yang amat strategis yakni sebagai alat pendidikan, sekaligus pembudayaan, karena kedua istilah yang amat dekat dan erat. Maknanya tidak lain adalah sebagai proses pengalihan dan penerimaan nilai-nilai. Dalam konteks keolahragaan secara menyeluruh, memang kian kita sadari perubahan yang terjadi sebagai dampak dari globalisasi dalam ekonomi yang dipacu oleh teknologi komunikasi juga terbawa dalam dunia olahraga (Coomb 2004:7).

Dalam pelaksanaan pendidikan jasmani dan olahraga yang menjadi perhatian yaitu: (1) pendidikan merupakan upaya penyiapan peserta didik menghadapi dan berperan dalam lingkungan hidup yang selalu berubah dengan cepat dan pluralistik; (2) pendidikan merupakan upaya peningkatan kualitas kehidupan pribadi masyarakat dan berlangsung seumur hidup; (3) pendidikan merupakan mekanisme sosial dalam mewariskan nilai, norma, dan kemajuan yang telah dicapai masyarakat; (4) pendidikan merupakan kiat dalam menerapkan prinsip-prinsip ilmu pengetahuan dan teknologi bagi pembentukan manusia 
seutuhnya; (5) dalam undang-undang RI No. 20 tahun 2003 tentang Sisdiknas disebutkan bahwa pendidikan adalah usaha sadar dan terencana untuk mewujudkan suasana belajar dan proses pembelajaran agar peserta didik secara aktif mengembangkan potensi dirinya untuk memiliki kekuatan spiritual keagamaan, pengendalian diri, kepribadian, kecerdasan, akhlak mulia, serta keterampilan yang diperlukan dirinya, masyarakat, bangsa dan negara.

\section{METODE PENELITIAN}

Mutu pendidikan yang belum maksimal menuntut guru-guru untuk melakukan perbaikan prestasi belajar dengan melakukan penelitian tindakan kelas, sehingga peneliti melakukannya di SMA Negeri 1 Kuta. Sekolah ini beralamat di jalan Dewi Saraswati Seminyak - Kuta, Telp./Fax ( 0361 ) 737 925. Perwujudan lingkungan yang aman, nyaman, tenang, rindang di sekolah ini telah diupayakan agar peserta didik senang dalam belajar. Dalam sebuah penelitian tindakan kelas perlu ada desain. Desain tersebut akan memberi arah terhadap pelaksanaan penelitian ini. Desain penelitian tindakan kelas ini diadopsi dari Suharsimi Arikunto, Suhardjono, Supardi (2006:58).

Sumber informasi untuk penelitian perlu ditentukan dengan maksud untuk mendapatkan data penelitian yang diinginkan. Adapun subjek dalam penelitian ini adalah semua siswa kelas XII.IPA 1 SMA Negeri 1 Kuta Semester I tahun pelajaran 2020/2021 berjumlah 36 orang. Objek penelitian merupakan sesuatu hal yang akan diteliti untuk mendapatkan data dengan tujuan tertentu dan kemudian dapat dijadikan pedoman untuk menarik kesimpulan. Untuk itu yang menjadi objek dalam penelitian ini adalah peningkatan prestasi belajar Penjasorkes siswa kelas XII.IPA 1 SMA Negeri 1 Kuta semester I tahun pelajaran 2020/2021 setelah penggunaan model pemberian perintah (model komando). Penelitian tindakan kelas yang dilakukan ini sudah terjadwal sedemikian rupa yaitu dari bulan Juli sampai bulan Nopember tahun 2020. Dalam penelitian ini, observasi dilakukan untuk memberikan penilaian terhadap keberhasilan metode pembelajaran yang telah dilaksanakan. Observasi dalam penelitian ini dilakukan menggunakan tes prestasi belajar. Hasil penelitian yang telah berhasil dikumpulkan berbentuk angka yang diperoleh menggunakan tes prestasi belajar selanjutnya akan dilakukan dianalisis secara deskriptif, dengan maksud untuk memberikan gambaran secara jelas tentang hasil penelitian yang diperoleh

\section{HASIL DAN PEMBAHASAN}

Proses pembelajaran dilakukan masih secara konvensional terhadap siswa kelas XII.IPA 1 SMA Negeri 1 Kuta yang jumlah siswanya 36 orang. Dalam penelitian ini proses pembelajaran pada awalnya dilakukan selama 3x pertemuan yaitu hari/tanggal: Rabu, 15, 22, dan 29 Juli 2020. Setelah itu dilakukan tes tertulis dan tes praktek diperoleh nilai rata-rata sebesar 79,58 dimana 3 siswa memperoleh nilai di atas KKM, 9 siswa memperoleh nilai sama dengan KKM dan 24 siswa memperoleh nilai di bawah KKM. Dengan demikian prosentase ketuntasan pada kegiatan baru tercapai 33,33\% dan nilai rata-rata kelas tersebut masih jauh di bawah KKM mata pelajaran Penjasorkes di sekolah ini sebesar 85,00. Penyebabnya adalah siswa kurang antusias dan kurang aktif dalam proses belajar dan mengajar, masih banyak siswa di kelas yang mengobrol teman teman sebangkunya saat proses belajar mengajar, guru mempergunakan model pembelajaran konvensional yaitu masih berupa ceramah.

Analisis kuantitatif prestasi belajar siswa siklus I: Rata-rata (mean) yang diperoleh dihitung dengan menjumlahkan seluruh nilai siswa kemudian dibagi dengan jumlah siswa diperoleh 84,97. Median (titik tengahnya) sebesar 85,00. Modus (nilai yang paling sering muncul) diperoleh dengan cara mengurutkan data (asscending) maka didapat nilai 85,00 
Tabel 1. Data Kelas Interval Siklus I

\begin{tabular}{ccccc}
\hline $\begin{array}{c}\text { No } \\
\text { Urut }\end{array}$ & Interval & $\begin{array}{c}\text { Nilai } \\
\text { Tepi }\end{array}$ & $\begin{array}{c}\text { Frekuensi } \\
\text { Absolut }\end{array}$ & $\begin{array}{c}\text { Frekuensi } \\
\text { Relatif }\end{array}$ \\
\hline 1 & $76-78$ & $75,5-78,5$ & 3 & 8,33 \\
2 & $79-81$ & $78,5-81,5$ & 4 & 11,11 \\
3 & $82-84$ & $81,5-84,5$ & 1 & 2,78 \\
4 & $85-87$ & $84,5-87,5$ & 17 & 47,22 \\
5 & $88-90$ & $87,5-90,5$ & 11 & 30,56 \\
6 & $91-93$ & $90,5-93,5$ & 0 & 0,00 \\
\hline Total & & & 36 & 100 \\
\hline
\end{tabular}

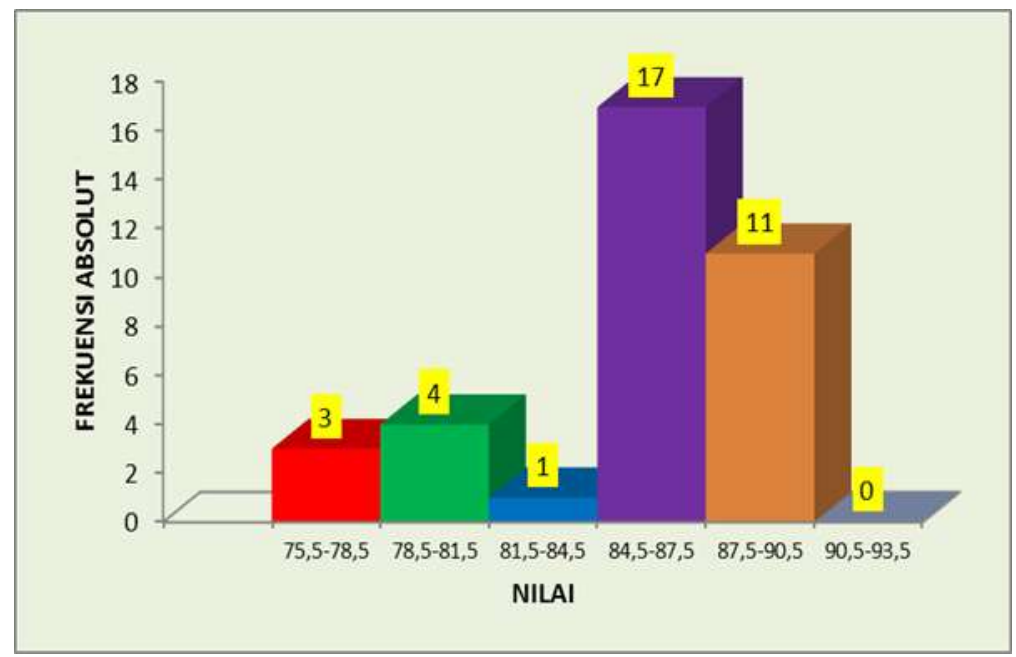

Gambar 1. Histogram Prestasi Belajar Siklus I

Analisis kuantitatif prestasi belajar siswa siklus II: Rata-rata (mean) yang diperoleh dihitung dengan menjumlahkan seluruh nilai siswa kemudian dibagi dengan jumlah siswa diperoleh sebesar 90,72. Median (titik tengahnya): 91,00. Modus (nilai yang paling sering muncul) diperoleh dengan cara mengurutkan data (asscending) maka didapat nilai 90,00.

Tabel 2. Data Kelas Interval Siklus II

\begin{tabular}{ccccc}
\hline $\begin{array}{c}\text { No } \\
\text { Urut }\end{array}$ & Interval & $\begin{array}{c}\text { Nilai } \\
\text { Tepi }\end{array}$ & $\begin{array}{c}\text { Frekuensi } \\
\text { Absolut }\end{array}$ & $\begin{array}{c}\text { Frekuensi } \\
\text { Relatif }\end{array}$ \\
\hline 1 & $85-86$ & $84,5-86,5$ & 6 & 16,67 \\
2 & $87-88$ & $86,5-88,5$ & 0 & 0,00 \\
3 & $89-90$ & $88,5-90,5$ & 11 & 30,56 \\
4 & $91-92$ & $90,5-92,5$ & 7 & 19,44 \\
5 & $93-94$ & $92,5-94,5$ & 9 & 25,00 \\
6 & $95-96$ & $94,5-96,5$ & 3 & 8,33 \\
\hline Total & & & 36 & 100,00 \\
\hline
\end{tabular}




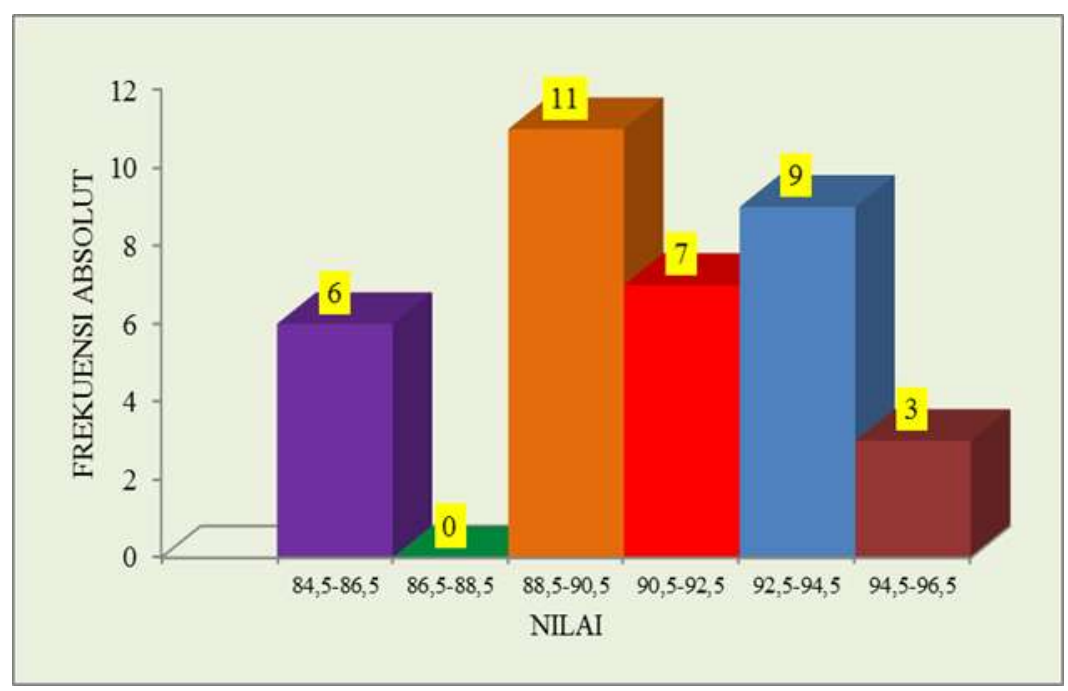

Gambar 2. Histogram Prestasi Belajar 2021 Siklus II

\section{KESIMPULAN DAN SARAN}

Simpulan yang dapat disampaikan berdasar semua temuan hasil penelitian adalah bahwa model pemberian perintah (model komando) yang telah dilaksanakan mampu menjawab rumusan masalah penelitian ini serta mampu membuktikan bahwa tujuan penelitian ini sudah dapat dicapai. Sebagai bukti atas pencapaian hal tersebut adalah:

Dari data awal ada 24 siswa mendapat nilai dibawah KKM dan pada siklus I menurun menjadi 8 siswa dan siklus II tidak ada siswa yang mendapat nilai di bawah KKM. Nilai ratarata awal 79,58 naik menjadi 84,97 pada siklus I dan pada siklus II naik menjadi 90,72. Dari data awal siswa yang tuntas hanya 12 siswa sedangkan pada siklus I menjadi lebih banyak yaitu 28 siswa dan pada siklus II menjadi tuntas semua sebanyak 36 siswa. Presentase yang diperoleh meningkat keberhasilannya. Dari data awal baru 33,33\% yang berhasil, pada siklus I meningkat menjadi $77,78 \%$ dan pada siklus II naik menjadi $100 \%$. Jadi dapat disimpulan penggunaan model pemberian perintah (model komando) dapat meningkatkan prestasi belajar Penjasorkes siswa kelas XII.IPA 1 semester I tahun pelajaran 2020/2021 di SMA Negeri 1 Kuta.

\section{UCAPAN TERIMAKASIH}

Ucapan terima kasih disampaikan kepada Kepala SMA Negeri 1 Kuta (Drs. I Ketut Sumandhi Arta, M.Pd) dan Bapak/Ibu guru SMA Negeri 1 Kuta

\section{DAFTAR PUSTAKA}

Agung, Anggana Y, 2002, Penelitian Tindakan Kelas, Departemen Pendidikan Nasional Direktorat Jendral Pendidikan Dasar dan Menengah Direktoral Jendral Pendidikan Lanjutan Pertama, Jakarta : Depdiknas

Arikunto, Suharsini, 1993, Manajemen Pengajaran Secara Manns iawi, Jakarta : PT Rineka Cipta.

Budaningsih, 2000, Penerapan Met ode Diskusi Dalam Meningkatkan Aktivitas Dan Hasil Belajar Siswa Dalam Pembelajaran Geografi IB SLTPN 1 Tegallalang (Skr Pendidikan Jasmani, olahraga, dan kesehatani tdk Diterbitkan), Singaraja: IKIPN. 
Dimyati dan Mudjiono, 1994, Belajar dan Pembelajaran, Jakarta : PT Rineka Cipta.

Hasibuan, J J dan Moedjiono, 1999, Proses Belajar Mengajar, Bandung : PT Rosdakarya.

Irianto, Agus, 2004, Statistk Konsep Dasar \& Aplikasinya, Jakarta : Fajar Interpratama Offset.

Rakhmat, Jalaludin, 2004, Metode penelitian Komunikasi, Bandung: PT Rosdakarya.

Roestiyah, N, K, 2001, Strategi Belajar Mengajar, Jakarta : PT Rineka Cipta.

Rohani Ahmad, 2004, Pengelolaan Pengajaran ( Edisi Revisi), Jakarta :PT Rineka Cipta.

Rineka Cipta, Sahertian, Piet, A, 2006, Konsep dasar da Teknik Supervisi Pendidikan, Jakarta :PT Rineka Cipta.

Sardinian, 2006, Interaksi Dan Motivasi Belajar Mengajar, Jakarta : PT Raja Grafindo Persada.

Slameto, 2003, Belajar dan Faktor-faktor Yang Mempengaruhinya, Jakarta : PT Rineka Cipta.

Sudjana, Nana, 2004, Penilaian Hasil Belajar Mengajar, Bandung : PT Remaja Rosdakarya.

Sukardi, Dewa Ketut, 1994, Bimbingan Karir di Sekolah-sekolah, Jakarta : CV. Ghalia Indonesia.

Suryosubroto, B. 2002. Proses Belajar Mengajar di Sekolah, Jakarta :PT. Renika Cipta.

Suyanto, 1997, Pedoman Pelaksanaan Penelitian Tindakan Kelas, Yogyakarta : Depdikbud.

Wiyanto Asul, 2000, Diskusi, Jakarta: PT. Grasindo 